УДК 378:373.3.011.3-051]:[7:005.336.2]

DOI:

Роксолана Шпіца, кандидат педагогічних наук, стариий викладач кафедри початкової освіти Київського університету імені Бориса Грінченка

Інна Федів, магістрантка Київського університету імені Бориса Грінченка

\title{
СТРУКТУРА МИСТЕЦЬКОЇ КОМПЕТЕНТНОСТІ МАЙБУТНЬОГО ВЧИТЕЛЯ ПОЧАТКОВИХ КЛАСІВ
}

У статті розглянуто й окреслено наукову проблематику мистецької компетентності майбутнього вчителя початкових класів. Уточнено сутність поняття на перетині дефініцій “компетентність" та “компетенція”. Означено тлумачення ключових та дотичних категорій у педагогічній літературі, їх зміст $i$ структуру. Спираючись на науково-педагогічні джерела, встановлено недостатню розробленість структури мистецької компетентності майбутнього вчителя. Відтак, висвітлено зміст і структуру означеного поняття. 3'ясовано, що наукового обтрунтування потребують педагогічні умови, методи та прийоми формування мистецької компетентності майбутнього педагога.

Ключові слова: компетентність; мистецька компетентність; початкова освіта; вчитель 1-4 класів; НУШ.

Puc. 1. Jim. 14.

Roksolana Shpitsa, Ph.D. (Pedagogy), Senior Lecturer of the Elementary Education Department, Pedagogical Institute, Kyiv Borys Hrinchenko University Inna Fediv, Master Student of Kyiv Borys Hrinchenko University

\section{THE STRUCTURE OF ARTISTIC COMPETENCE OF FUTURE PRIMARY SCHOOL TEACHER}

The article considers the essence of the concepts "competence", "competence", "artistic competence of future primary school teachers" and on the basis of the theoretical analysis of the researched problem the structure of artistic competence of the future primary school teacher is outlined. The polar views on its solution and the essence of the phenomenon at the intersection of tangent definitions are clarified. The generalization of the experience of domestic and foreign scholars allowed us to formulate the definition of "artistic competence of the future primary school teacher" as follows: as a personal quality and the result of understanding the specifics of the artistic component of their own professional activity in the field of various arts during their practical mastery. The author considered the structural components of the competence of the future teacher proposed by scientists and adapted their scientific research to the plane of our study. Therefore, we propose the structure of artistic competence of the future primary school teacher in which we distinguish three components: personal-motivational, cognitive-reflexive and creative-organizational. Thus, the first component includes a set of personal traits necessary for a primary school teacher in teaching an integrated course "Art" and the formation of motives for the implementation of pedagogical support. The availability of the necessary knowledge of art (knowledge of song repertoire and works for listening) (grades 1-4), mastering basic knowledge of musical instruments, the ability to assess their own professional artistic activity and make appropriate adjustments became the basis of cognitive-reflexive component, preparation and organization of project, concert and extracurricular art work. Their combination and interaction comprehensively outline the essence of the basic category. Additional scientific justification requires pedagogical conditions, methods and techniques for the formation of artistic competence of future teachers, which we see prospects for further research. School.

Keywords: competence; artistic competence; primary education; teacher of grades 1-4; New Ukrainian

$\Pi$ остановка проблеми. Сучасні суспільні виклики та умови модернізації національної системи освіти детермінують переосмислення досвіду теорії і практики підготовки педагогів початкової школи. Це зумовлено актуальними суспільними пріоритетами, що передбачають інтенсифікація інтеграційних процесів. Вони безпосередньо впливають на освітню систему. Вона покликана забезпечити підготовку майбутнього вчителя, який буде компетентний у багатьох аспектах. Відповідно, змінюються вимоги до компетентнісного рівня студентів. Майбутньому вчителю належить пройти нелегкий шлях професійного становлення у площині набуття фахових, зокрема предметних компетентностей та життєвих, мистецька серед яких займає чільне місце. Вона передбачає особистісно-ціннісне ставлення до мистецтва, знання композицій для виконання / слухання та мистецького тезаурусу, розуміння мови та засобів 
виразності видів мистецтва, розвиток пізнавальних процесів (зокрема оперування художніми образами), творчої самостійності та здатності спілкуватися мовою мистецтва на різних рівнях комунікації організовуючи мистецькопедагогічну та проєктну діяльність в ЗОШ. Уміння розв' язувати зазначені завдання - важлива умова якісного рівня фахової компетентності студента - майбутнього вчителя початкової школи. Названа проблематика розглядається здебільшого у контексті професійної музичної освіти та підготовці майбутніх учителів музичного мистецтва. У контексті ж підготовки вчителя початкових класів та розвитку його мистецької компетентності наукових досліджень бракує. Відтак у цій площині визначення змісту та структури мистецької компетентності не має достатнього освітлення у роботах вчених і потребує уточнення.

Аналіз останніх досліджень і публікацій. Дослідженню проблеми професійної підготовки викладачів та філософії сучасної вищої освіти присвячені праці В. Андрущенка, В. Огневїюка, В. Кременя. Становлення дефініції “компетентність” та “компетенція” розглядали у психологопедагогічних та дидактичних джерелах I. Зимня, К. Вельде, О. Локшина, Р. Майєрс, О. Пометун, О. Дубасенюк, Ч. Тінтін, С. Лейко. Питання формування компетентності майбутніх учителів педагогічних та мистецьких спеціальностей досліджувалася багатьма вченими. Цінними $є$ студії В. Берека та А. Галаса стосовно розвитку професійної компетентності вчителя початкових класів у методичному аспекті. У мистецькій освіті вищої школи виділяємо наукові праці Г. Падалка, Г. Ніколаї, А. Соколової. Актуальні питання підготовки майбутнього вчителя початкової школи до реалізації завдань мистецько-освітньої діяльності репрезентують у наукових здобутках учені країн Європейського Союзу Е. Мартісаускіне, Р. Віткаускас, Ж. Ринкевичюс, М. Санжаревская, М. Радванська, Я. Фігель. Визначенню сутності та структурі професійної компетентності присвячені роботи Л. Анциферової, Ю. Варданян, А. Маркової, Дж. Равена. Структуру компетентності вчителя у мистецькій сфері вивчали Н. Лупак та О. Семенова.

Мета статті - уточнити сутність понять “компетенція”, “компетентність”, “мистецька компетентність майбутніх учителів початкових класів” та на основі теоретичного аналізу досліджуваної проблеми окреслити структуру мистецької компетентності майбутнього вчителя початкових класів.

Виклад основного матеріалу дослідження. Широкий пласт наукових розвідок, що розкриває сутність категорії “компетентність” та їі структури, свідчить про зацікавленість вченими зазначеною проблематикою. На сьогодні існує декілька полярних поглядів щодо їі розв'язання. Для уточнення сутності поняття мистецької компетентності майбутніх учителів початкової школи та їі структури, розглянемо сутність феномену на перетині дотичних дефініцій.

У довідкових джерелах термін “compete” у дослівному перекладі означає “відповідати, бути здатним, годящим”, а поняття “competentia” відповідність, узгодженість; приналежність по праву, здатність до змагання. У Словнику іншомовних слів та Великому тлумачному словнику сучасної української мови категорія “компетентність” трактується як обізнаність, поінформованість, авторитетність, а “компетенція" - коло повноважень якої небудь організації або особи. Зі свого боку, “компетентний” - той, який має достатній рівень знань у якій небудь галузі; кваліфікований, грунтується на знанні, з чим небудь гарно обізнаний, тямущий.

Так, експертами країн Європейського Союзу визначено поняття "компетентність" як “здатність застосування знання й уміння активне застосування навчальних досягнень у нових ситуаціях". А саме поняття компетентності включає набір знань, навичок і ставлень, що дають змогу діяти або виконувати певні функції, які спрямовані на досягнення певних стандартів у професійній галузі чи діяльності” [13, 8-9].

У наукових дослідженнях існують різні точки зору стосовно зазначеної проблематики. Окреслимо деякі з них.

Вітчизняний науковець М. Головань пропонує ототожнювати значення поняття "компетентність" та “компетенція". У наукових розвідках автор спирається на англомовні джерела, в яких застосовується слово "competency", яке має ті самі значення, що й “competence”. Крім того, зазначає автор, - на основі аналізу етимологічної інформації тлумачного словника, "competency" перекладається як “компетенція” [3, 224-233].

Підтвердження цієї думки знаходимо у Глосарії термінів ЕФО (Свропейський фонд освіти, 1997 р.). Саме тут вищезазначені поняття використовуються в одних і тих самих значеннях: “Здатність виконувати особливі трудові функції” $[5,12]$.

Для більш детального розкриття означеної проблематики звернемося до трактувань цих категорій сучасними науковцями.

Так, вітчизняна дослідниця Т. Росул у своїх наукових розвідках детально розглядає компетенції майбутніх учителів початкових класів у контексті мистецької освіти. Авторка підтримує 
точку зору авторитетних науковців про потребу диференціації понять “компетенція" та “компетентність”, проте зазначає, що донині існує певна їх термінологічна невизначеність [8, 83 88]. Спираючись на Закон України "Про вищу освіту” [4, 1-2] та Професійний стандарт вищої освіти України за спеціальністю 013 Початкова освіта (затверджений 23.03.2021) р. [9, 1-2], вона зазначає, що підготовка фахівців передбачає виховання соціально зрілої особистості та передбачає сформованість у майбутнього педагога загальних і професійних компетентностей. А фахову компетентність вчителя початкової школи пропонує розглядати як інтеграцію когнітивного, предметно-практичного та особистісноорієнтованого досвіду особистості.

Суголосні погляди натрапляємо у наукових дослідженнях Р. Шпіци. Вона, розглядаючи категорію “компетентність", також акцентує увагу на полярності поглядів дослідників стосовно диференціації зазначених категорій. Так, авторка виділяє науковців, які ототожнюють, або вважають за доцільне використовувати їх як слова-синоніми (Дж. Равен, Д. Ільязова та ін.) та розмежовують поняття “компетенція" та “компетентність" (О. Семеног, М. Рижков, Л. Болотов та ін.) $[13,50]$.

Детально розглянувши феномен компетентності, науковець виокремлює ключові визначення, що його характеризують. Серед них: “"знання досвід в тій або іншій галузі”; “базова характеристика особи”; “деякі внутрішні, потенціальні психологічні новоутворення, які потім виявляються в діяльності”; “інтегративна характеристика якості підготовки випускника"; “комплекс умінь, знання в діï”; “здатність, готовність, спроможність”; “якість особистості”; “специфічна здатність, необхідна для ефективного виконання конкретної дії в конкретній галузі, яка охоплює вузькоспеціальні знання, специфічні предметні навички, способи мислення, розуміння відповідальності за власні дії”. Відтак, авторка пропонує розрізняти зазначені терміни і не ототожнювати їх $[13,54]$.

Науковець А. Хуторський також детально розглядає зазначені поняття. Розмежовуючи їх, він трактує “компетенцію” як коло питань, у яких людина добре обізнана, має певний досвід. Зі свого боку “компетентність” розглядається як поєднання знань, здібностей у певній галузі, що дають змогу обгрунтовано охарактеризувати цю сферу та активно діяти в ній. Водночас, компетентність трактується як певна освіченість, майстерність, обдарованість тощо. А “компетенція" - як маленький елемент широкого поняття компетентності [10, 58-64].
Так, у спеціальній літературі наукового, практичного та методичного характеру визначено специфіку компетентності, яка формується засобами мистецтва. У цьому контексті важливе значення мають дослідження Л. Масол. Вона акцентує увагу на тому, що “під час спілкування особистості з художніми цінностями у перебігу загального духовного зростання особистості іiі мистецькі знання, власний досвід, ціннісні художні орієнтації за певних умов повинні трансформуватися в художньо-естетичні компетентності”, які зі свого боку відображають інтегровані результати навчання у галузі мистецтва та сформовані особистісні якості. Вона узагальнює досвід своїх попередників і формулює визначення мистецької компетентності як здатність до розуміння і творчого самовираження у сфері різних видів мистецтва і їх практичного опанування [6, 58-64].

На думку О. Олексюк, мистецька компетентність відображає духовний потенціал особистості, їі здатність до емоційно-ціннісного світопереживання, готовність створювати творчий стиль життя й діяльності на основі досвіду використання мистецьких компетенцій. Дослідниця розглядає мистецьку компетентність як єдність “знань 3 історії, теорії, методики викладання мистецтва, зокрема музичного, художньо-творчих умінь у галузі виконавства та досвіду практичної художньо-освітньої діяльності” [7, 112-116]. Водночас вітчизняна вчена розглядає поняття мистецької компетентності майбутнього вчителя музики ширше, ніж компетенції, виокремлюючи у складі категорії цілу низку предметних компетенцій, які охоплюють різні види музичної діяльності майбутніх педагогів. Серед них:

- здатність до вільного оперування мистецькими знаннями; проведення художніх паралелей між стильовими напрямами й жанрами музики та інших видів мистецтв; відтворення об'єктивного змісту твору і вираження суб'єктивного ставлення до музики; педагогічно доцільного добору репертуару;

- уміння мобільно застосовувати наявні знання в контексті конкретного музичного твору;

- дотримання стильових засад виконавства; артистичного втілення інтерпретаційного задуму в реальному звучанні;

- спроможність визначати навчальновиховний потенціал музичного твору.

Узагальнення досвіду зазначених науковців дає нам змогу сформулювати визначення “мистецької компетентності майбутнього вчителя початкових класів" як особистісну якість та результат усвідомлення специфіка мистецької складової 
власної професійної діяльності, що передбачає інтеграцію знань з теорії та методики викладання мистецтва, творчого самовираження та рефлексії у сфері різних видів мистецтва під час їх практичного опанування.

У контексті розгляду структури мистецької компетентності виокремлюємо педагогічний та мистецький аспекти.

У професійно-педагогічному дискурсі структуру “компетентності” майбутнього вчителя у педагогічній площині розглядала плеяда вітчизняних науковців. Серед них: І. Шмиголь, О. Білостоцька, Т. Бондаренко, Л. Шерстюк та iH.

Так, дослідник I. Шмиголь, досліджуючи проблему формування професійної компетентності, педагога визначає таку iii структуру, що складається 3 дев'яти компонентів. Серед них автор виокремлює: мотиваційний, спеціальнопредметний, психолого-педагогічний, особистісний, комунікативний, організаційно-управлінський, е ксп е ри мен тальн о - дослі дницький, рефлективність та самостійність. Він наголошує, що всі структурні компоненти професійної компетентності вчителя взаємозалежні та взаємопов'язані [12, 197-204].

Зі свого боку вітчизняна вчена О. Білостоцька, здійснюючи авторський аналіз структури професійної компетентності майбутнього викладача, окреслює такі компоненти: мотиваційно-ціннісний, когнітивний, діяльнісний, регулятивно-рефлексивний компоненти. Вона переконана, що саме їх взаємодія та поєднання сприяють комплексному розумінню змісту поняття “компетентності" [1, 74-78].

Екстраполюючи наукові пошуки Т. Бондаренко у сферу педагогіки вищої школи, зазначимо, що науковець, розглядаючи структуру методичної компетентності, виділяє три компоненти. До них дослідник відносить когнітивний, емоційноціннісний та діяльнісно-практичний. Автор підтримує точку зору попередніх науковців про єдність всіх компонентів та їх взаємодію для розкриття базового поняття [2, 150-155].

Варто виділити результати наукових розвідок сучасної дослідниці Л. Шерстюк. Вона розглядає компетентність викладача як сукупність конструктивно-проєктувальної діяльності, рефлексії та володіння предметними, психологопедагогічними, науково-методичними знаннями. Науковиця визначає дві взаємовідповідальні складові (блоки) компетентності: вміння здійснювати традиційну педагогічну діяльність та вміння проєктувати педагогічні інновації [11, 220 224.].
Ми погоджуємось, що методична компетентність учителя має базуватись на традиційному педагогічному досвіді, але за умови впровадження в освітній процес інноваційних методів та підходів.

У контексті мистецької освіти структуру базового поняття “мистецька компетентність майбутнього педагога”, прямо та опосередковано розглядали такі вітчизняні науковці: А. Козир, Г. Падалка, О. Олексюк, Л. Масол В. Орлова та ін. Науковці зазначають, що професійна компетентність учителів мистецтва містить низку компонентів. Серед них, на їхню думку, особливого значення набувають: особистісний (сукупність особистісних рис, необхідних для вчителя мистецтва); мотиваційний (сформованість мотивів до здійснення професійної діяльності вчителя мистецтва); когнітивний (наявність необхідних знань з мистецтвознавчих дисциплін, а також знань із суміжних дисциплін, що необхідні для роботи); операційний (сформованість умінь і навичок практичного розв'язання професійних завдань), рефлексивний (здатність оцінювати власну професійну діяльність, зробити певні висновки, визнавати помилки, вносити відповідні корективи). Розглянувши розв'язання наукової проблеми зазначеними авторами, адаптуємо їхні наукові погляди у площину нашого дослідження.

Розглянувши подані вище структурні складові компетентності майбутнього вчителя, пропонуємо таку структуру мистецької компетентності майбутнього вчителя початкової школи. Відтак, виокремлюємо три компоненти, серед яких виділяємо: особистісно-мотиваційний, когнітивнорефлексивний та творчо-організаційний. Їх поєднання та взаємодія комплексно окреслюють суть базової категорії. Так, перший компонент включає сукупність особистісних рис, необхідних для вчителя початкових класів при викладанні інтегрованого курсу “Мистецтво” та сформованість мотивів до здійснення педагогічного супроводу. Наявність необхідних знань з мистецтва (знання пісенного репертуару і творів для слухання (1-4 класи), оволодіння елементарними знаннями 3 музичного інструмента, здатність оцінювати власну професійну мистецьку діяльність та вносити відповідні корективи стають основою когнітивно-рефлексивного компонента. Останній компонент включає творчу діяльність педагога, підготовку та організацію проектної, концертної та позашкільної мистецької роботи.

Висновки. Досліджуючи задеклароване дискусійне питання та підтримуючи думку авторитетних науковців, ми розглянули багатовимірність зазначених понять. 3'ясовано, що терміни "компетенція" та "компетентність" 


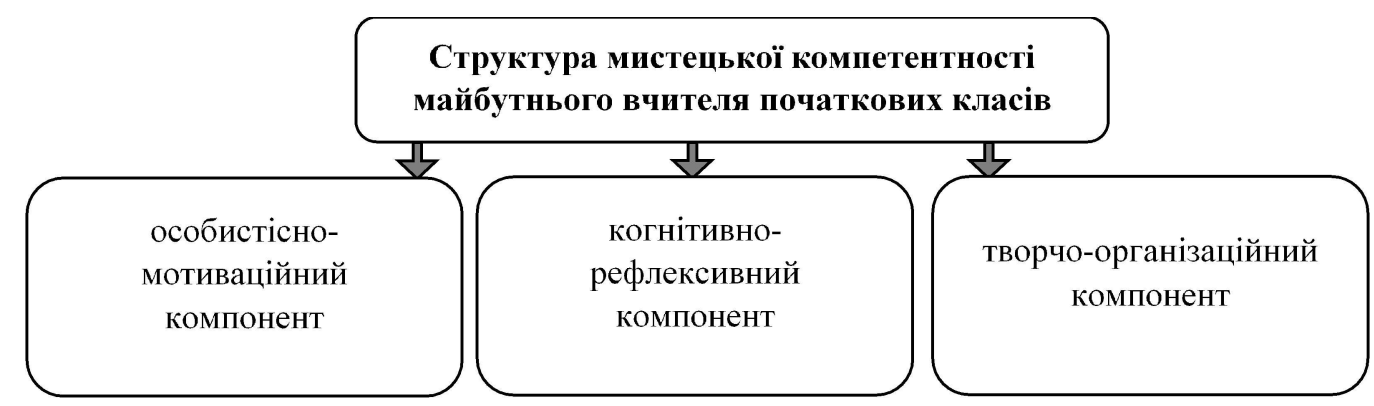

Рис. 1. Структура мистецької компетентності майбутнього вчителя початкових класів

потрібно розрізняти. Розкрито поняття “мистецька компетентність майбутнього вчителя початкових класів" та подача його структура. Базову категорію визначаємо як особистісну якість та результат усвідомлення специфіки мистецької складової власної професійної діяльності, що передбачає інтеграцію знань $з$ теорії та методики викладання мистецтва, творчого самовираження та рефлексії у сфері різних видів мистецтва під час їх практичного опанування. У структурі мистецької компетентності майбутнього вчителя початкових класів пропонуємо виокремлювати три складові компоненти: особистісномотиваційний, когнітивно-рефлексивний та творчо-організаційний. Додаткового наукового обгрунтування потребують педагогічні умови, методи та прийоми формування мистецької компетентності майбутнього педагога, у чому вбачаємо перспективу для подальшого дослідження.

\section{ЛІТЕРАТУРА}

1. Білостоцька О. В. Компоненти та критерії професійної компетентності майбутнього викладача музичного мистецтва. Інноваційна педагогіка. Причорномор. наук.-дослід. ін-т економіки та інновацій. Одеса. 2019. Т. 1, № 18. С. $74-78$.

2. Бондаренко Т. С. Визначення змісту, структури та етапів формування методичної компетентності у майбутніх учителів біології. Проблеми підготовки сучасного вчителя. Умань. 2012. № 5(2). С. 150-155.

3. Головань М.С. Компетенція та компетентність: порівняльний аналіз понять. Педагогічні науки: теорія, історія, інновачійні технологї. Суми. 2011. №8. С. 224-233.

4. Закон України “Про вищу освіту”. Відомості Верховної Ради. 2014. № 37-38. C.2004.URL: https://zakon.rada.gov.ua/laws/show/1556-18\#Text (дата звернення: 13.06.2021)

5. Зимняя И.А. Ключевые компетентности как результативная целевая основа компетентностного подхода в образовании. Москва. 2004, 42c. URL: www.rc.edu.ru

6. Масол Л. М. Загальна мистецька освіта : теорія і практика : монографія. Київ: Промінь, 2006. 432 с.

7. Олексюк О. М. Музична педагогіка: навч. посібник. Київ. Київ. ун-т ім. Б. Грінченка, 2013. $248 \mathrm{c.}$

8. Росул Т. І. Формування "4К” - компетенцій майбутніх вчителів початкових класів засобами оперного мистецтва, Молодь і ринок. Щомісячний науково-педагогічний журнал. Дрогобич. 2021. №5-6 (191-192). С. $83-88$.

9. Стандарт вищої освіти України ступеня бакалавра,спеціальності 013 "Початкова освіта". (2021). URL:https://mon.gov.ua/ua/osvita/vishaosvita/naukovo-metodichna-rada-ministerstva-osvitii-nauki-ukrayini/zatverdzheni-standarti-vishoyi-osviti (дата звернення:08.06.2021).

10. Хуторской А.В. Ключевые компетенции как компонент личностно-ориентированной парадигмы образования. Народное образование. Москва, 2003. №2. C.58-64.

11. Шерстюк Л.В. Сутність та структура методичної компетентності майбутнього викладача-філолога. Вісник Чернігівського національного педагогічного університету. Серія: Педагогічні науки. Чернігів, 2017. № 142. С. 220 224.URL:http://nbuv.gov.ua/UJRN/VchdpuP_2017_142_50 (датазвернення: 29.07.2020).

12. Шмиголь I.А. Сутність та структура професійної компетентності педагога. Проблеми підготовки сучасного вчителя. 2011. Т. 1, № 4. C. 197-204. URL: http://nbuv.gov.ua/UJRN/ ppsv_2011_4(1)_32 (дата звернення : 13.08.2020)

13. Шпіца Р. І. Категорія “компетентність” як наукова проблема педагогічної освіти. Науковий часопис НПУ ім. М. П. Драгоманова. Серія 14. Теорія і методика мистецької освіти: збірник наукових праць. Випуск 15(20). Київ: Вид-во НПУ ім. М. П. Драгоманова, 2013. С.49-54.

\section{REFERENCES}

1. Bilostotska, O. V. (2019). Komponenty ta 
kryterii profesiinoi kompetentnosti maibutnoho vykladacha muzychnoho mystetstva [Components and criteria of professional competence of a future music teacher]. Black Sea Research Institute of Economy and Innovation. Odessa, no.18. pp. 7478. [in Ukrainian].

2. Bondarenko, T. S (2012). Vyznachennia zmistu, struktury ta etapiv formuvannia metodychnoi kompetentnosti u maibutnikh uchyteliv biolohii [Determining the content, structure and stages of formation of methodological competence in future biology teachers]. Problems of modern teacher training. Uman, no. 5(2). pp. 150-155. [in Ukrainian].

3. Holovan, M.S. (2012). Kompetentsiia ta kompetentnist: porivnialnyi analiz poniat [Competence and competence: a comparative analysis of concepts]. "Pedagogical sciences: theory, history, innovative technologies". Sumy, no. 8. pp 224-233. [in Ukrainian].

4. Zakon Ukrainy "Pro vyshchu osvitu" (2014). [Law of Ukraine "On Higher Education"]. Information of the Verkhovna Rada. No. 37-38. Available at: https://zakon.rada.gov.ua/laws/show/ 1556-18\#Text (accessed 13 June 2021). [in Ukrainian].

5.Zimnyaya, I.A. (2004). Klyuchevye kompetentnosti kak rezultativnaya tselevaya osnova kompetentnostnogo podkhoda $\mathrm{v}$ obrazovanii [Key competencies as an effective target basis for a competency-based approach in education]. Research Center for the Problems of the Quality of Training of Specialists. Moscow, p. 42. Available at: www.rc.edu.ru [in Russian].

6. Masol, L.M. (2016). Zahalna mystetska osvita : teoriia i praktyka [General art education: theory and practice]. Kyiv, p. 432. [in Ukrainian].

7. Oleksiuk, O. M. (2013). Muzychna pedahohika [Music pedagogy]. Textbook. Borys Grinchenko Kyiv University, Kyiv, p. 248. [in Ukrainian].

8. Rosul, T. I. (2021). Formuvannia " $4 \mathrm{~K}$ " kompetentsii maibutnikh vchyteliv pochatkovykh klasiv zasobamy opernoho mystetstva [Formation of " $4 \mathrm{~K}$ " - the competencies of future primary school teachers by means of oper]. "Youth and market". Monthly scientific pedagogical journal. Drogobych, №5-6 (191-192). pp. 83 - 88. [in Ukrainian].

9. Standart vyshchoi osvity Ukrainy stupenia bakalavra,spetsialnosti 013 "Pochatkova osvita" (2021). [Standard of higher education of Ukraine bachelor's degree, specialty 013 "Primary education"]. Available at: https://mon.gov.ua/ua/ osvita/visha-osvita/naukovo-metodichna-radaministerstva-osviti-i-nauki-ukrayini/zatverdzhenistandarti-vishoyi-osviti (accessed 08 June 2021) [in Ukrainian].

10. Khutorskoy, A.V. (2003). Klyuchevye kompetentsii kak komponent lichnostnoorientirovannoy paradigmy obrazovaniya [Key competencies as a component of a student-centered education paradigm]. Public education, Moscow, no. 2 pp. 58-64. [in Russian].

11. Sherstiuk, L.V. (2017). Sutnist ta struktura metodychnoi kompetentnosti maibutnoho vykladachafiloloha [The essence and structure of methodological competence of the future teacher-philologist]. Bulletin of the T.H. Shevchenko National University "Chernihiv Colehium", Chernihiv, no. 142. pp. 220-224. Available at: http://nbuv.gov.ua/ UJRN/VchdpuP_2017_142_50 (accessed 07 July. 2020) [in Ukrainian].

12. Shmyhol, I. A. (2011). Sutnist ta struktura profesiinoi kompetentnosti pedahoha [The essence and structure of professional competence of a teacher]. Problems of modern teacher training. Uman, no. 4. pp. 197-204. Available at: http:// nbuv.gov.ua/UJRN/ppsv_2011_4(1)_32 (accessed 13 August. 2020) [in Ukrainian].

13. Shpitsa, R. I. (2013). Katehoriia "kompetentnist" yak naukova problema pedahohichnoi osvity [Rank "competence" as a scientific problem of pedagogical education]. Scientific Journal of National Pedagogical Dragomanov University, Series 14. Theory and methods of art education: a collection of scientific papers, Kyiv, no. 14. pp.49-54, [in Ukrainian].

Стаття надійшла до редакції 04.10.2021

\section{G58089}

“Слідкуй за свойми думками; вони стануть словами.

Слідкуй за свойми словами; вони стануть діями.

Слідкуй за свойми діями; вони стануть звичқою.

Слідқуй за свойми звичқами; вони стануть образом.

Слідкуй за свойм образом; він стане долею".

1ao-I구 $3 u$

китайський білософ

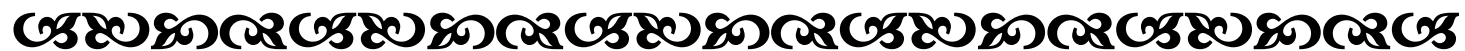

